\title{
BRCA1 Gene Mutation Screening for the Hereditary Breast and/or Ovarian Cancer Syndrome in Breast Cancer Cases: a First High Resolution DNA Melting Analysis in Indonesia
}

\author{
Farmaditya EP Mundhofir ${ }^{1 *}$, Catharina Endah Wulandari ${ }^{1}$, Yan Wisnu Prajoko ${ }^{2}$, \\ Tri Indah Winarni ${ }^{1}$
}

\begin{abstract}
Specific patterns of the hereditary breast and ovarian cancer (HBOC) syndrome are related to mutations in the BRCA1 gene. One hundred unrelated breast cancer patients were interviewed to obtain clinical symptoms and signs, pedigree and familial history of $\mathrm{HBOC}$ syndrome related cancer. Subsequently, data were calculated using the Breast and Ovarian Analysis of Disease Incidence and Carrier Estimation Algorithm (BOADICEA) risk prediction model. Patients with high score of BOADICEA were offered genetic testing. Eleven patients with high score of BOADICEA, 2 patients with low score of BOADICEA, 2 patient's family members and 15 controls underwent BRCA1 genetic testing. Mutation screening using PCR-HRM was carried out in 22 exons (41 amplicons) of $B R C A 1$ gene. Sanger sequencing was subjected in all samples with aberrant graph. This study identified 10 variants in the $B R C A 1$ gene, consisting of 6 missense mutations $(c .1480 \mathrm{C}>\mathrm{A}, \mathrm{c} .2612 \mathrm{C}>\mathrm{T}, \mathrm{c} .2566 \mathrm{~T}>\mathrm{C}$, c.3113A>G, c.3548 A>G, c.4837 A>G), 3 synonymous mutations (c.2082 $\mathrm{C}>\mathrm{T}, \mathrm{c.2311} \mathrm{T}>\mathrm{C}$ and $\mathrm{c} .4308 \mathrm{~T}>\mathrm{C})$ and one intronic mutation $(c .134+35 \mathrm{G}>\mathrm{T})$. All variants tend to be polymorphisms and unclassified variants. However, no known pathogenic mutations were found.
\end{abstract}

Keywords: HBOC syndrome - BRCAl gene - Indonesian population - PCR-HRM - BOADICEA

Asian Pac J Cancer Prev, 17 (3), 1539-1546

\section{Introduction}

Breast cancer is the most common cancer in Indonesian females with incidence rate approximately 36.2 in 100,000 and in the top ten of mortality cause with mortality incidence is 18.6 in 100,000 among other diseases (Azis et al., 2009; Wahidin et al., 2012). Roughly 5-10\% of breast cancer cases related to the Hereditary Breast and/ or Ovarian (HBOC) syndrome. Individuals with HBOC syndrome have significantly higher lifetime risk of breast cancer development compare to general population (life time risk to age 70 for breast cancer is $60-80 \%$ ). Specific pattern of HBOC syndrome is related to specific mutation in the BRCA1 or BRCA2 gene (Mary et al., 2012; Petrucelli et al., 2013).

Compared to BRCA2, BRCAl has higher prevalence related to $\mathrm{HBOC}$; it is 1 in 300 per 100,000 population, while BRCA2 gene only 1 in 800 (Mary et al., 2012). $B R C A 1$ gene is located in chromosome $17 \mathrm{q} 21$. The main function is maintaining chromosome stability through DNA damage repair process and regulation process of cell cycle checkpoint as the response to DNA damage.
Mutation in genomic region of BRCAl contributes to genetic instability. Chromosomal instability caused by deficiency of BRCAl thought to be pathogenic basic in breast cancer development (NCBI, 2013; Petrucelli et al., 2013).

Identification of hereditary breast cancer through family history and pedigree construction are cost-effective method. Several models and scoring systems have been designed to assess the probability of $B R C A 1$ mutation in an individual based on family history. However, among of these models, the Breast and Ovarian Analysis of Disease Incidence and Carrier Estimation Algorithm (BOADICEA) appeared to be the most accurate for assessing the risk of breast cancer (Evans et al., 2007; Stahlbom et al., 2012). Data from BOADICEA provides risk estimation of BRCAI gene mutation for each individual which is included in pedigree construction. These data could direct clinicians to consider the highest risk-individual to undergo genetic testing for further assessment.

This study was designed to identify patient who were predisposed to BRCAl-related HBOC syndrome in Indonesia using BOADICEA. Genetic testing was 
Farmaditya EP Mundhofir et al

performed in individual with high score of BOADICEA result by using Polymerase Chain Reaction-High Resolution Melting Analysis (PCR-HRM). This is the first study using PCR-HRM in Indonesia.

\section{Materials and Methods}

\section{Study population}

One hundred unrelated breast cancer patients from Oncology surgery and Chemotherapy Department of Dr. Kariadi Hospital were included. Data obtained from interview including history of the disease, pedigree and family history of cancer related HBOC syndrome were analyzed by BOADICEA risk prediction software. The study was conducted in compliance with the Helsinki Declaration. Ethical clearance had been obtained from Ethical Committee for Medical Research Faculty of Medicine, Diponegoro University - Dr. Kariadi Hospital and written informed consent was obtained from all participants involved in this study.

\section{DNA extraction and high resolution melting (HRM)}

Genomic DNA was extracted using salting out method from venous blood samples. DNA quantification and qualification were estimated using Spectrophotometer (GE-NanoVue). To cover all exons of BRCAl gene, 41 primers were used according to previous study (Ava Kwong et al., 2012) for HRM mutation screening. DNA amplification was performed by 36 plates RotorGeneQ 5Plex HRM (Qiagen, California, USA). RotorGene Q 5Plex HRM (Qiagen, California, USA) was used for PCR-HRM amplification. Each reaction was performed in a final volume of $20 \mu$ containing $10 \mu$ l Type-It HRM Master Mix (Qiagen, California, USA), $4 \mu$ primer (5 pM forward and reverse primer), $2 \mu$ DNA $10 \mathrm{ng}$ and $\mathrm{H} 2 \mathrm{O}$ up to $20 \mu \mathrm{l}$. The PCR profile was performed as follows: pre-activation at $950 \mathrm{C}$ for 5 minute, followed by 40 cycles of denaturation at $950 \mathrm{C}$ for 10 seconds, 30 seconds annealing at 54-620C and 10 seconds extension at $720 \mathrm{C}$. HRM amplification were done at $60-980 \mathrm{C}$ with $0.10 \mathrm{C}$ temperature increment. Melting curve was analyzed by Rotor Gene - Pure Detection version 2.1.0 (build 9) (Qiagen, California, USA) software. Afterwards, aberrant patterns were sequenced using Sanger sequencing method.

\section{Mutation analysis}

The sequence analysis was compared to the reference from NCBI BRCAI referred sequence: NC_000017.10. The previous known mutations were accessed in The UMD-BRCAl mutations database website (http://www. umd.be/BRCA1/4DACTION/W_DMDT1/11) last updated June 2015, NCBI (http://ncbi.gov.nih) and Ensembl (http://ensembl.org). The Alamut version 2.4-7 software has been used for the interpretation of the new sequence variants and for the detection of splicing aberrations caused by the new unclassified variants detected in our present study. Alamut can predict the severity of amino acid substitutions by integrating nucleotide and amino acid conservation, by prediction methods including the Sorting Intolerant From Tolerant (SIFT), Align-Grantham Variation with Grantham Deviation (A-GVGD), and
Mutation Taster.

\section{Results}

A hundred samples had been collected from August to December 2014. Data collection was done through interview about clinical history, risk factors, pedigree construction and family history of HBOC syndrome related cancer. Collected data then were calculated using BOADICEA software risk prediction model to determine the suspect of hereditary breast cancer. Fourteen of 100 patients with BOADICEA score $\geq 1.5$ were offered for genetic testing. However, 4 of them refused to do genetic testing. There was one patient with diagnosis of Fibro

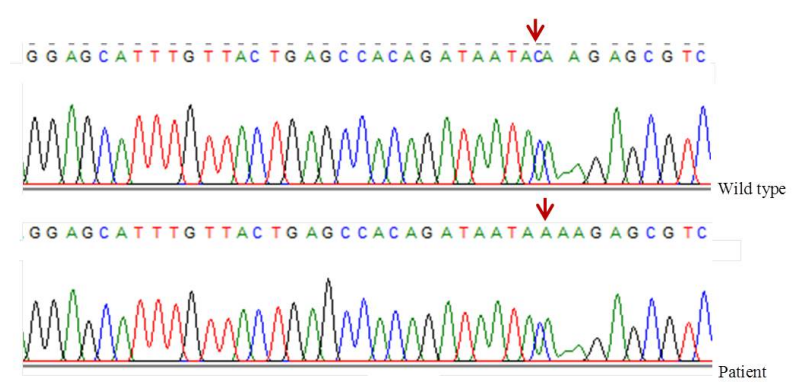

Figure 1. Sequence Result of a Normal Individual (Wild Type) and Breast Cancer Patient with Missense Mutation in c.1480C>A/p.GIn494Lys in Exon 11-4

Supplement Table 1. Sample Characteristics and Risk Factors of Breast Cancer

\begin{tabular}{|c|c|c|}
\hline Variable & Total (person) & Percentage $(\%)$ \\
\hline \multicolumn{3}{|l|}{ Onset } \\
\hline$>60$ y.o & 7 & 7 \\
\hline $50-60$ у.о & 24 & 24 \\
\hline $40-50$ у.о & 37 & 37 \\
\hline $30-40$ у.о & 26 & 26 \\
\hline$<30$ y.o & 6 & 6 \\
\hline \multicolumn{3}{|l|}{ Menarche age } \\
\hline$\geq 12$ y.o & 100 & 100 \\
\hline$<12$ y.o & 0 & 0 \\
\hline \multicolumn{3}{|l|}{ First parital age } \\
\hline$>30$ y.o & 16 & 16 \\
\hline \multicolumn{3}{|c|}{ "or have not had children or unmarried" } \\
\hline$\leq 30$ y.o & 84 & 84 \\
\hline \multicolumn{3}{|l|}{ Contraception history } \\
\hline Hormonal & 60 & 60 \\
\hline Non hormonal & 6 & 6 \\
\hline "No contraseption" & 34 & 34 \\
\hline \multicolumn{3}{|l|}{ Menopausal age } \\
\hline$>55$ y.o & 1 & 1 \\
\hline$\leq 55$ y.o & 53 & 53 \\
\hline Premenopausal & 46 & 46 \\
\hline \multicolumn{3}{|c|}{ "Positive family history of cancer related HBOC syndrome" } \\
\hline Yes & 13 & 13 \\
\hline No & 87 & 87 \\
\hline \multicolumn{3}{|c|}{ "Having previous non-cancerous disease of breast " } \\
\hline Yes & 5 & 5 \\
\hline No & 95 & 95 \\
\hline \multicolumn{3}{|c|}{ "History of radiation in chest" } \\
\hline Yes & 8 & 8 \\
\hline No & 92 & 92 \\
\hline
\end{tabular}


DOI:http://dx.doi.org/10.7314/APJCP.2016.17.3.1539

BRCA1 Mutation Screening in Breast Cancer Cases: a First High Resolution DNA Melting Analysis in Indonesia

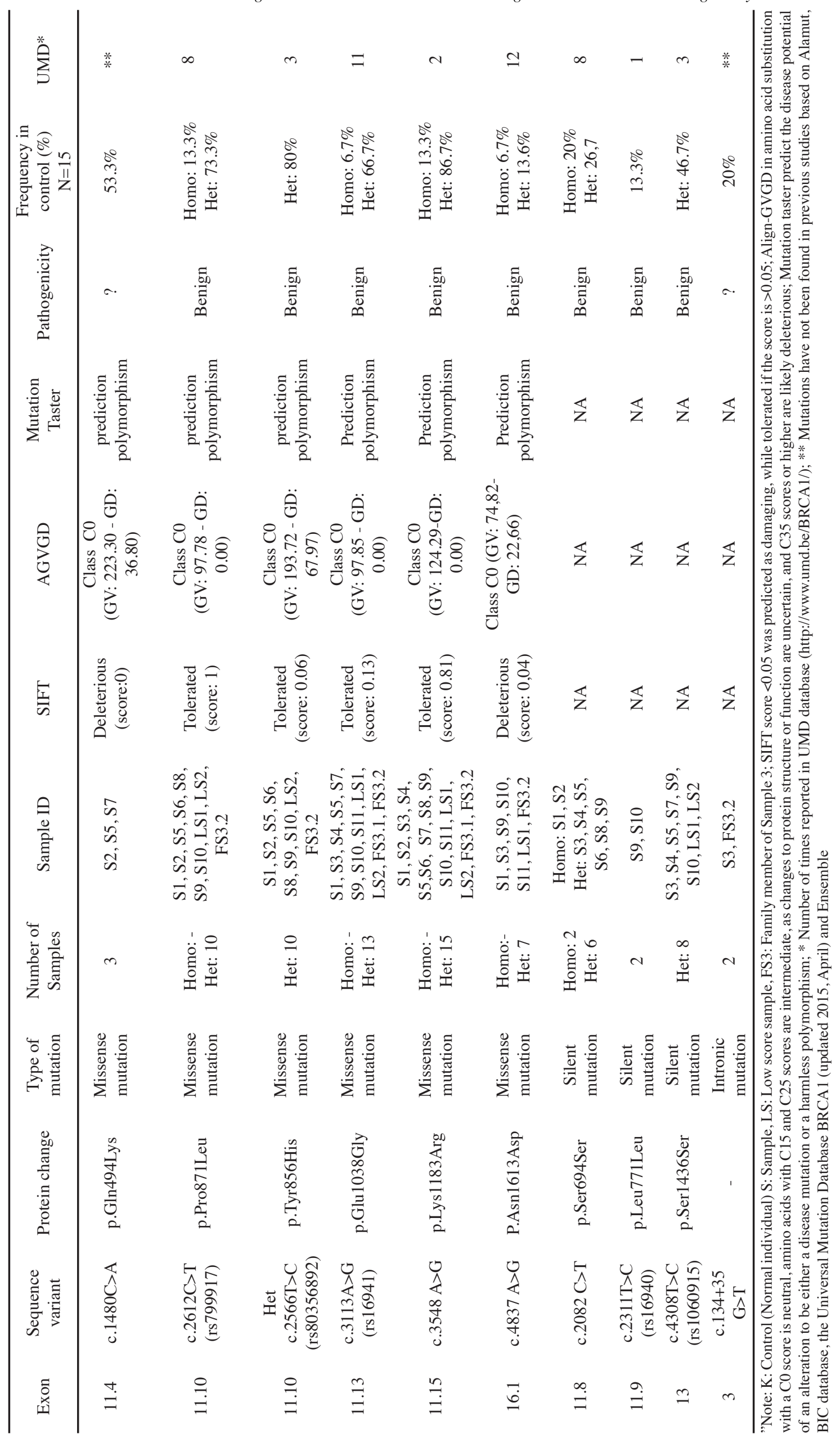


Table 2. Characteristics of Patients with High BOADICEA Scores

\begin{tabular}{|c|c|c|c|c|c|c|c|c|c|c|}
\hline \multirow[t]{2}{*}{ Initial } & \multirow{2}{*}{$\begin{array}{l}\text { Sample } \\
\text { ID }\end{array}$} & \multirow[t]{2}{*}{ Age } & \multirow{2}{*}{$\begin{array}{l}\text { Onset of } \\
\text { breast } \\
\text { cancer }\end{array}$} & \multirow[t]{2}{*}{ Diagnosis } & \multirow[t]{2}{*}{ Stadium } & \multirow{2}{*}{$\begin{array}{l}\text { Family history } \\
\text { of cancer }\end{array}$} & \multirow{2}{*}{$\begin{array}{l}\text { Hormonal } \\
\text { testing } \\
\text { result }\end{array}$} & \multicolumn{2}{|c|}{$\begin{array}{l}\text { BOADICEA } \\
\text { score* }\end{array}$} & \multirow[t]{2}{*}{ Note } \\
\hline & & & & & & & & BRCA1 & BRCA2 & \\
\hline GT & S1 & 40 & $\begin{array}{c}37 \\
(\mathrm{MD}) \\
39(\mathrm{MS})\end{array}$ & $\begin{array}{l}\text { IDC grade II } \\
\text { MD post op+ } \\
\text { IDC grade II } \\
\text { MS }\end{array}$ & IIIC & $\begin{array}{l}\text { Uncle: soft } \\
\text { tissue carsinoma } \\
\text { of neck }\end{array}$ & - & 4.4 & 13.5 & \\
\hline $\mathrm{SN}$ & $\mathrm{S} 2$ & 56 & 54 & $\begin{array}{c}\text { IDC grade II } \\
\text { MS }\end{array}$ & IV & $\begin{array}{c}\text { Sister, mother: } \\
\text { BC }\end{array}$ & - & 1.7 & 4 & \\
\hline MT & S3 & 51 & $\begin{array}{c}46 \text { (MS) } \\
49 \\
(\mathrm{MD})\end{array}$ & $\begin{array}{l}\text { IDC grade II } \\
\text { MS post op+ } \\
\text { IDC grade II } \\
\text { MD }\end{array}$ & IIIC & $\begin{array}{l}\text { Uncle, cousin: } \\
\text { soft tissue } \\
\text { carcinoma }\end{array}$ & $\begin{array}{l}\text { ER: neg } \\
\text { PR: neg } \\
\text { HER2: } \\
\text { neg }\end{array}$ & 4.7 & 4.0 & \\
\hline PR & S4 & 33 & 28 & $\begin{array}{c}\text { Adeno Ca } \\
\text { mammae } \\
\text { mucoides MS }\end{array}$ & IIIB & Sister: FAM & - & 22.1 & 15.3 & \\
\hline SL & S5 & 43 & 43 & $\begin{array}{c}\text { IDC grade III } \\
\text { MS }\end{array}$ & IIIB & Cousin: BC & - & 1.5 & 1.5 & \\
\hline $\mathrm{SC}$ & - & 34 & 32 & $\begin{array}{l}\text { IDC grade III } \\
\text { MD }\end{array}$ & IIIB & - & - & 2.2 & 2.0 & $\begin{array}{l}\text { Refused } \\
\text { to do } \\
\text { genetic } \\
\text { testing }\end{array}$ \\
\hline $\mathrm{JM}$ & S6 & 60 & $\begin{array}{c}40(\mathrm{MS}) \\
52 \\
(\mathrm{MD})\end{array}$ & $\begin{array}{l}\text { IDC grade } \\
\text { III MS, IDC } \\
\text { grade II MD }\end{array}$ & IV & $\begin{array}{l}\text { Grandmother: } \\
\text { BC }\end{array}$ & - & 1.8 & 3.3 & \\
\hline KT & S7 & 40 & 40 & $\begin{array}{l}\text { IDC grade II } \\
\text { MD }\end{array}$ & IIIB & $\begin{array}{c}\text { Mother's sister: } \\
\text { BC }\end{array}$ & - & 1.3 & 1.9 & \\
\hline $\mathrm{CM}$ & - & 32 & 30 & IDC grade II & & $\begin{array}{c}\text { Mother's sister: } \\
\text { BC }\end{array}$ & - & 2.8 & 2.2 & $\begin{array}{c}\text { Refused } \\
\text { to do } \\
\text { genetic } \\
\text { testing }\end{array}$ \\
\hline UY & - & 35 & 34 & $\begin{array}{c}\text { IDC grade III } \\
\text { MD }\end{array}$ & IIIB & - & - & 1.9 & 1.7 & $\begin{array}{l}\text { Refused } \\
\text { to do } \\
\text { genetic } \\
\text { testing }\end{array}$ \\
\hline $\mathrm{IM}$ & S9 & 44 & 44 & $\begin{array}{c}\text { IDC grade II } \\
\text { MS }\end{array}$ & IIB & $\begin{array}{l}\text { Mother's sister: } \\
\text { BC } \\
4 \text { cousins: BC }\end{array}$ & - & 1.6 & 1.5 & \\
\hline $\mathrm{BN}$ & $\mathrm{S} 10$ & 40 & $\begin{array}{c}38 \text { (MS) } \\
40 \\
(\mathrm{MD})\end{array}$ & ILC MS & IV & $\begin{array}{c}\text { Sister: Bilateral } \\
\text { FAM }\end{array}$ & - & 9.3 & 7.5 & \\
\hline SH & S11 & 39 & 39 & $\begin{array}{c}\text { IDC grade II } \\
\text { MS }\end{array}$ & IIB & $\begin{array}{c}\text { Mother: } \\
\text { Ovarian cancer } \\
\text { Mother's sister: } \\
\text { BC }\end{array}$ & $\begin{array}{l}\text { ER: neg } \\
\text { PR: neg }\end{array}$ & 1.7 & 1.5 & \\
\hline & & & & & & & HER2: +3 & & & \\
\hline $\mathrm{NH}$ & - & 43 & 40 & $\begin{array}{c}\text { IDC grade II } \\
\text { MS }\end{array}$ & IIIB & $\begin{array}{l}\text { Father's sister: } \\
\text { BC }\end{array}$ & $\begin{array}{c}\text { ER: neg } \\
\text { PR: neg } \\
\text { HER2: } \\
\text { neg }\end{array}$ & 2.1 & 0.6 & $\begin{array}{l}\text { Refused } \\
\text { to do } \\
\text { genetic } \\
\text { testing }\end{array}$ \\
\hline
\end{tabular}

"IDC: Invasive Ductal Carcinoma; MD: Mammae dextra; MS: Mammae sinistra; BC: Breast cancer; ER: Estrogen Receptor; PR: Progestron Receptor; HER2: Human Epithelial Receptor 2; *Score of $\geq 1.5$ was defined as high risk of harboring BRCA1 gene mutation“

Adenoma Mammae (FAM) included in this study due to family history of cancer-related HBOC syndrome (grandmother of the father and two father's cousins suffering from breast cancer as well as having two older sisters with FAM). There were two family members of patients who did not have breast cancer but had high score of BOADICEA (sample ID: FS3.1 and FS3.2) and 2 patients with low score of BOADICEA (Sample ID: 
LS1 and LS2) were randomly selected for genetic testing. Controls in this study were 15 women without breast cancer sign and familial history of cancer related to HBOC syndrome. In total there were 15 patients and 15 controls were carried out for genetic testing. The characteristics of patients and risk factors for breast cancer was shown in supplementary data, Table 1 and the characteristics of patients who have a high score for BOADICEA risk prediction model result was summarized in Table 2.

According to classification in Universal Mutation Database for BRCAl gene mutation and using Alamut 2.4.7 software for the interpretation of the new sequence variants, we identified 10 variants consist of 6 missense mutations, 3 silent/synonymous mutations and 1 intronic mutation. Five out of six variants (c.2612 C > T, c.2566 T> C, c. $3113 \mathrm{~A}>\mathrm{G}, \mathrm{c} .3548 \mathrm{~A}>\mathrm{G}$ and c. $4837 \mathrm{~A}>\mathrm{G})$ and three variants of synonymous mutation (c.2082 C > T, c.2311 T> $\mathrm{C}$ and c.4308T $>\mathrm{C}$ ) have been reported in previous studies as polymorphism with uncertain clinical significance; however it was suspected to be benign. While variant of c.1480C >A/p.Gln494Lys found in this study was novel. In present study, these variants were found in the most of samples (both normal controls and patients with breast cancer). Therefore, these variants tend to be polymorphism in Indonesian population.

One missense mutation has not been recorded in the database and has not been reported by previous studies. Variants of c.1480 C > A was predicted by SIFT as deleterious (0). However according to AGVGD it was in Class C0 (GV: 223.30 - GD: 36.80) and polymorphism by Mutation tasters. This mutation was found in most of the controls ( 8 of 15 control) and 3 patients.

Intronic mutation (c. $134+35 \mathrm{G}>\mathrm{T}$ ) was found in three controls and two patients. This mutation was not on the splicing site according to Human Splice Site Finder Software version 3.0 (available online in http://www.umd. be/HSF3/). Therefore, it did not alter the protein function of the protein and has no clinical impact.

To confirm the result, we performed sequencing of all BRCAl gene exons in one patient with highest BOADICEA score (sample

\section{Discussion}

To date, only few reports have been published about the spectrum of BRCAl sequence variants in Indonesian population (Purnomosari et al., 2007; Kwong et al., 2015). It is interesting that the younger onset of breast cancer was identified in $68 \%$ (68 of 100 patients). Furthermore, $85.3 \%$ of them (58 of 68 patients) did not have a family history of HBOC syndrome-related cancer. Several studies have been reported that breast cancer in Asia presents at a younger mean age compared to Western population (Yip et al., 2009; 2010; Pathy et al., 2011; Mousavi S., 2013). In Asia, the age specific rates for breast cancer onset were increased after menopause and peaked around 50 years and then decreased and plateaued afterward. For the European population, the age specific rates peaked between 55 to 75 years and then slightly decreased (Matsuno et al., 2007; Leong et al., 2010). This younger mean age is likely due to the population pyramid structure in developing countries, which have a broad base indicating a higher fertility rate. Therefore, the proportion of women in the older age groups are lower compared to Western countries (Ng et al., 2011).

Although breast cancer in Asia tend to have younger onset, breast cancer on age fewer than 50 years old at the time of diagnosis during 2008 were less than $50 \%$ (incidence rate $42 \%$ in Asia-Pacific region and $47 \%$ within the sub region of South-Eastern Asia) (Youlden et al., 2014). Malaysia as neighbor country of Indonesia only has incidence of breast cancer $48.1 \%$ below age $50(\mathrm{Ng}$ et al., 2011). It may suggest that other factor than genetic play a role in the tendency of younger onset in Indonesian breast cancer population.

There are several studies suggested that oral contraceptive was associated with an increased breast cancer risk (Gierisch et al., 2011; Beaber et al., 2014). In Indonesia, hormonal contraceptive use increases risk of cancer (approximately 2 times) (Harianto et al., 2005; Sirait et al., 2009). Mammography screening implementation can affect the onset of breast cancer (Glass et al., 2007; Brown et al., 2009). Currently, Indonesia does not have population-based breast cancer screening program. This is due to socio-economic development problems, hence breast cancer probably considered as 'low priority' compared to infectious diseases by the health care system in Indonesia. Thus, it leads them to be less responsive to breast cancer care in terms of early detection, breast health education and creating awareness (Ng et al., 2011). In addition, other recognized barriers for early detection of breast cancer in the Asian region include belief in traditional medicine and lack of autonomy in decision making (Norsa'adah et al., 2011; Taib et al., 2011). These barriers may be more prevalent in poorer countries (Ng et al., 2011). Other factors that can increase risk of younger onset in breast cancer were BMI index and environmental factors (Nichols et al., 2009; Cecchini et al., 2012; Assi et al., 2013). No previous study in Indonesia about these factors and their impact in breast cancer risk. Therefore, future studies are warranted.

A number of variants have been identified in this study. There are five missense mutations that have been reported in previous studies as polymorphism (p.Pro871Leu c.2612 C>T (Cherbal et al., 2012; Akilzhanova et al., 2013), p.Tyr856His c.2566 T>C (Herrick et al., 2006), p.Glu1038Gly c.3113 A>G (Akilzhanova et al., 2013), p.Lys1183Arg c.3548 A>G (UMD-BRCA1, 2015) and p.Asn1613Asp c.4837 A $>$ G (Cherbal et al., 2012). Silent mutation at c.2082C $>\mathrm{T}$ was found in most of the samples, either homozygous or heterozygous. This variant has been reported by previous studies in a population of Argentinean and Kazakhstan populations as single nucleotide polymorphism (Cherbal et al., 2012; Akilzhanova et al., 2013). This variant has also been recorded in the ensemble data base as a normal variant (rs1799949). Variant in c.2311T $>C$ have been reported previously in several studies as a polymorphism (Keshavarzi et al., 2012; Berzina et al., 2013). Therefore, the existence of both mutations in this study tends to be normal variant that will not cause disease.

To date, several studies have evaluated risk associated 
of breast and/or ovarian cancer with SNPs in BRCA1. However, results from these studies showed conflicting evidence (Dombernowsky et al., 2009; Pilato et al., 2010; Medimegh et al., 2014). Variants of c.2082C $>$ T, c. $3113 \mathrm{~A}>\mathrm{G}$ and c.3548A $>\mathrm{G}$ SNPs were not associated with breast cancer disease with $\mathrm{P}$ value $<0.05$. Whereas variants of c.2311T $>C$, c.2612 $\mathrm{C}>\mathrm{T}$ and c.4308T $>\mathrm{C}$ are clearly associated with familial breast cancer with an odds ratio ranging from 2.49 to 4.66. Among these SNPs, the c.2612 C $>$ T variant could have an effect on amino acid change (Proline to Leucine) at position 871, suggesting an alteration on the protein function that can play a role in familial breast cancer susceptibility (Medimegh et al., 2014). However, in other study evaluated risk associated of breast and/or ovarian cancer by missense polymorphisms in BRCAl c. $2612 \mathrm{C}>\mathrm{T}$, c. $3113 \mathrm{~A}>\mathrm{G}$ and c. $4837 \mathrm{~A}>\mathrm{G}$, found no association between heterozygosity or homozygosity for those polymorphisms and risk of breast and/or ovarian cancer (Dombernowsky et al., 2010). The other study found that SNPs BRCA1 c.3548A>G/ p.Lys1183Arg was more frequently present in breast cancer relatives who were tested negative (Pilato et al., 2010).

In this study, those known missense polymorphism were found in many patients; heterozygous mutation of c. $2612 \mathrm{C}>\mathrm{T}$ (10 patients, $66.7 \%)$, heterozygous mutation of c. $2566 \mathrm{~T}>\mathrm{C}$ (10 patients, $66.7 \%)$, heterozygous mutation of c.3113A $>\mathrm{G}$ (13 patients, 86.7\%), heterozygous mutation c.3548 $\mathrm{A}>\mathrm{G}$ (15 patients, 100\%), heterozygous mutation c.4837 A>G (7 patients, 46.7\%), c.2082C $>\mathrm{T}$ (homozygous: 2 patients, $13.3 \%$; heterozygous: 8 patients, $53.3 \%)$, c. $2311 \mathrm{~T}>\mathrm{C}(2$ patients, $13.3 \%)$, and heterozygous mutation of c.4308T >C (8 patients, $53.3 \%$ ), respectively. Interestingly, all patients have multiple variants and no known pathogenic mutation found. Several missense polymorphisms detected in our patients who were tested negative for BRCAl gene mutations, may have a role in breast cancer susceptibility marker. However, evaluation study with larger samples and healthy controls are required.

Variant of c.1480C> A p.Gln494Lys has not been found in previous study. This variant was found in 3 patients $(20 \%)$ and 8 normal controls $(53.3 \%)$. It is suggested a polymorphism although on In Silico analysis, c.1480C $>$ A is Deleterious (0) by SIFT, but Class C0 (GV: 223.30 - GD: 36.80) by AGVGD and prediction polymorphism by Mutation Taster. There are 2 patients with this variant having young onset of breast cancer (40 and 43 years). Both are having invasive ductal carcinoma in histopathological finding and have family history of cancer related HBOC syndrome. Further study is required to investigate whether this mutation is only polymorphism or potential to be pathogenic.

Intronic mutation (c. $134+35 \mathrm{G}>\mathrm{T}$ ) was found in three controls and two patients. There is no previous studies that mention this mutation. This mutation was not found on the splicing site according to Human Splice Site Finder Software version 3.0 (available online in http://www.umd. be/HSF3/). Therefore, it not alters the protein function of the protein and has no impact clinically.

Specific pattern of HBOC syndrome are linked to mutation in BRCA1 or BRCA2 genes. However, there are many other genes such as TP53, PTEN, also related to hereditary breast cancer in a rare case (Pilarski et al., 2009; Schneider et al., 2010; Petrucelly et al., 2013). Several studies have been conducted and they indicate that mutations of BRCA genes in Asian breast cancer patients are occur at similar rates compared to other racial groups, with prevalence rate $12.7 \%$. Except for Pakistani and Indian patients, $B R C A 2$ mutations in the Asian population were detected equally, or more frequently than $B R C A 1$ mutations when compared to other ethnicities (Haffty et al., 2009; Hall et al., 2009). BRCA1 gene mutation in breast cancer patients have been studied in Indonesia using multiplex ligation-dependent probe amplification (MLPA) method. Samples were 136 breast cancer patients from Jakarta, Yogyakarta and Denpasar. That study found three pathogenic mutation (c.2784_2875insT, p.Leu1415x and del exon 13-15) and 20 "unclassified variants" with uncertain clinical consequences. However, only $7.8 \%$ of patients at high risk for hereditary breast cancer had BRCA1/2 mutation (BRCA1: $2.6 \%, B R C A 2$ : $5.2 \%$ ) (Purnomosari et al., 2007). A Pilot Genome-wide Association Study of Breast Cancer Susceptibility Loci in Indonesia was performed in 89 breast cancer patients. It was reported 11 chromosome loci that possessed suggestive associations with breast cancer risk. However all subjects with breast cancer were negative for mutations in BRCA1 and BRCA2 genes (Haryono et al., 2015). This result suggesting that probably $B R C A 1 / 2$ genes are not common related to HBOC syndrome in Indonesia. However further study with larger sample are required.

In conclusion, we identified 10 variants in $B R C A l$ gene that tend to be polymorphism and unclassified variants. No known pathogenic mutation found. This is the first study in Indonesia for risk and mutational analysis using PCRHRM in breast cancer patients. Limitation of this study was small size of samples due to financial constraints. In addition, hormonal data (ER, PR and HER2) could not be obtained since they are not common diagnostic test in Indonesia for breast cancer individuals. These hormonal data affect to the BOADICEA calculation though. Our study shows that PCR-HRM can be considered as costeffective screening method especially for low-income country like Indonesia.

\section{Acknowledgements}

The authors would like to thank all the study participants. We would like to thank to Surgical Oncology and Chemotherapy Division staff, Dr. Kariadi Hospital, Semarang for the assistance in collecting sample process and Biomedical Research Center (CEBIOR) staff for providing laboratory tools support. This study was financially supported by a grant from DIPA PNBP UNDIP funding No.213-09/UN7.5.1/pg/2014 and Beasiswa Unggulan DIKTI scholarship.

\section{References}

Akilzhanova A, Nyshanbekkyzy N, Nurkina Z, et al (2013). $B R C A 1$ and $B R C A 2$ gene mutations screening in sporadic breast cancer patients In Kazakhstan. Central Asian J Global 
Health, $2,29$.

Azis F (2009). Gynecological cancer in Indonesia. J Gynecol Oncol, 20, 8-10.

Assi H, Khoury K, Dbouk H, et al (2013). Epidemiology and prognosis of breast cancer in young women. $J$ Thorac Dis, 5, 2-8

Beaber E, Buist D, Barlow W, et al (2014). Recent oral contraceptive use by formulation and breast cancer risk among women 20 to 49 years of age. Cancer Res, 74, 4078-89.

Berzina D, Miklasevica M, Jekaterina Z, et al (2013). BRCA1/2 mutation screening in high-risk breast/ovarian cancer families and sporadic cancer patient surveilling for hidden high-risk families. BMC Medical Genetics, 14, 61.

Brown S, Morrison D, Cooke T (2009). Increasing incidence of breast cancer: distinguishing between the effects of birth cohort and a national breast screening programme. Breast Cancer Res Treat, 116, 603-7.

Cecchini R, Constantio J, Culey J, et al (2012). Body mass index and the risk for developing invasive breast cancer among high-risk women in NSABP P-1 and STAR breast cancer prevention Trials. Cancer Prev Res, 5, 583-92.

Cherbal F, Salhi N, Bakour R, et al (2012). BRCA1 and BRCA2 unclassified variants and missense polymorphisms in Algerian breast/ovarian cancer families. Dis Markers, 32, 343-53.

Dombernowsky S, Weischer M, Freiberg J, et al (2009). Missense polymorphisms in BRCA1 and BRCA2 and risk of breast and ovarian cancer. Cancer Epidemiol Biomarkers Prev, 18, 2339-41.

Evans G, Howell A (2007). Breast cancer risk-assessment models. Breast Cancer Res, 9, 1750.

Genetics Home Reference. 2013. BRCA1. Accessed December 15, 2013, at http://ghr.nlm.nih.gov/ gene/BRCA1.

Gierisch J, Coeytaux R, Urrutia R, et al (2014). Oral contraceptive use and risk of breast, cervical, colorectal, and endometrial cancers: a systematic review. Cancer Epidemiol Biomarkers Prev, 22, 1931-43.

Glass A, Lacey J, Carreon J, et al (2007). Breast cancer incidence, 1980-2006: combined roles of menopausal hormone therapy, screeningmammography, and estrogen receptor status. $J$ National Cancer Institute, 99, 1152-61.

Haffty B, Choi D, Goyal S, et al (2009). Breast cancer in young women (YBC): prevalence of $B R C A 1 / 2$ mutations and risk of secondary malignancies across diverse racial groups. Ann Oncol, 20, 1653-9.

Hall M, Reid J, Burbidge L, et al (2009). BRCA1 and BRCA2 mutations in women of different ethnicities undergoing testing for hereditary breast-ovarian cancer. Cancer, 115, 2222-33.

Harianto, Mutiara R, Surachmat H (2005). The Risk of The Combination of Oral Contraception with Breast Cancer Incidence of Outpatient Clinic in Cipto Mangunkusumo Hospital. Majalah Ilmu Kefarmasian, 22, 84-99.

Haryono S, Datasena I, Santosa W, et al (2015). A pilot genomewide association study of breast cancer susceptibility loci in Indonesia. Asian Pac J Cancer Prev, 16, 2231-5.

Herrick B, Scally M, Madsen A, et al (2006). Natural selection and mammalian $B R C A 1$ sequences: elucidating functionally important sites relevant to breast cancer susceptibility in humans. Mamm Genome, 17, 257-70.

Keshavarzi F, Javadi G, Zeinali S (2012). BRCA1 and BRCA2 germline mutations in 85 Iranian breast cancer patients. Familial Cancer, 11, 57-67.

Kwong A, On N, Wong C, et al (2012). Identification of BRCA1/2 founder mutations in southern Chinese breast cancer patients using gene sequencing and high resolution dna melting analysis. PLOS One, 7, 43994.

Kwong A, Shin V, Ho J, et al (2015). Comprehensive spectrum of $B R C A 1$ and $B R C A 2$ deleterious mutations in breast cancer in Asian countries. J Med Genet, 53, 103132.

Leong S, Shen Z, Liu T, et al (2010). Is breast cancer the same disease in asian and western countries? World J Surg, 34, 2308-24.

Mary B, Jennifer E, Saundra B, et al (2012). NCCN clinical practice guidelines in oncology genetic/familial highrisk assessment: breast and ovarian version I. National Comprehensive Cancer Network.

Matsuno R, Anderson W, Yamamoto S, et al (2007). Early- and late-onset breast cancer types among women in the united states and Japan. Cancer Epidemiol Bio-markers Prev, 16, 1437-42.

Medimegh I, Troudi W, Stambouli N, et al (2014). Wild-type genotypes of BRCAl gene SNPs combined with micro RNA over-expression in mammary tissue leading to familial breast cancer with an increased risk of distant metastases occurrence. Med Oncol, 31, 11.

Mousavi S, Kasaeian A, Mansori K, et al (2013). Addressing the younger age at onset in breast cancer patients in asia: an age-period-cohort analysis of fifty years of quality data from the international agency for research on cancer. Oncol, 2013, 429862.

$\mathrm{Ng} \mathrm{CH}$, Pathy B, Taib N, et al (2011). Comparison of breast cancer in Indonesia and Malaysia - a clinico-pathological study between Dharmais Cancer Centre Jakarta and University Malaya Medical Centre, Kuala Lumpur. Asian Pac J Cancer Prev, 12, 2943-46.

Nichols H, Trentham A, Egan K, et al (2009). Body mass index before and after breast cancer diagnosis: associations with all-cause, breast cancer, and cardiovascular disease mortality. Cancer Epidemiol Biomarkers Prev, 18, 1403-9.

Norsa'adah B, Rampal K, Rahman M, et al (2011). Diagnosis delay of breast cancer and its associated factors in Malaysian women. BMC Cancer, 11, 141.

Pathy N, Yip C, Taib N, et al (2011). Breast cancer in a multiethnic Asian setting: results from the Singapore-Malaysia hospital-based breast cancer registry. Breast, 20, S75-80.

Petrucelli N, Daly M, Feldman G (2013). BRCAl and BRCA2 hereditary breast and ovarian cancer.

Pilarski R (2009). Cowden syndrome: a critical review of the clinical literature. J Genet Couns, 18, 13-27.

Pilato B, Martinucci M, Danza K, et al (2010). Mutations and polymorphic BRCA variants transmission in breast cancer familial members. Breast Cancer Res Treat, 125, 651-7.

Purnomosari D, Pals G, Wahyono A, et al (2007). BRCAl and $B R C A 2$ germline mutation analysis in the Indonesian population. Breast Cancer Res Treat, 106, 297-304.

Schneider K, Garber J (2010). Li-Fraumeni syndrome. Acessed at November 25, 2014, at http://www.ncbi.nlm.nih.gov/ books/NBK1311/.

Sirait A, Oemiati R, Indrawati L (2009). Hubungan kontrasepsi pil dengan tumor/kanker payudara di Indonesia. Maj Kedokt Indon, 59, 348-56.

Stahlbom A, Johansson H, Liljegren A, et al (2012). Evaluation of the BOADICEA risk assessment model in women with a family history of breast cancer. Familial Cancer, 11, 33-40.

Taib N, Yip C, Low W (2011). Recognising symptoms of breast cancer as a reason for delayed presentation in Asian women - The Psycho-socio-cultural Model for breast symptom appraisal: opportunities for intervention. Asian Pacific $J$ Cancer Prev, 12, 1-8.

UMD-BRCAl mutations database.. 2015. BRCAl gene mutation. Accessed April 15, 2015, at http://www.umd.be/BRCA1/

Wahidin M, Noviani R, Hermawan S, et al (2012). Population- 
Farmaditya EP Mundhofir et al

based cancer registry in Indonesia. Asian Pac J Cancer Prev, 13, 1709-10.

Yip C (2009). Breast cancer in Asia. Methods Mol Biol, 471, 51-64.

Yip C, Cazap E, Anderson B, et al (2010) Breast cancer management in middle-resourcecountries (MRCs): consensus statement from the breast health global initiative. Breast, 20, 12-9.

Youlden D, Cramb S, Yip C, et al (2014). Incidence and mortality of female breast cancer in the Asia-Pacific region. Cancer Biol Med, 11, 101-15. 